\title{
Morphology of the atrioventricular valves and related intraventricular structures in the wild pig (Sus scrofa)
}

\author{
S. Ateş ${ }^{1}$, E. Karakurum ${ }^{2}$, L. Takcı ${ }^{1}$, F. Başak ${ }^{3}$, i. Kürtül ${ }^{4}$ \\ ${ }^{1}$ Department of Anatomy, Faculty of Veterinary Medicine, Mustafa Kemal University, Hatay, Turkey \\ ${ }^{2}$ Department of Anatomy, Faculty of Veterinary Medicine, Mehmet Akif Ersoy University, Burdur, Turkey \\ ${ }^{3}$ Department of Histology and Embryology, Faculty of Medicine, Karabuk University, Karabuk, Turkey \\ ${ }^{4}$ Department of Anatomy, Faculty of Medicine, Karabük University, Karabük, Turkey
}

[Received: 22 February 2017; Accepted: 12 May 2017]

\begin{abstract}
Morphology of the atrioventricular valves and the intraventricular related structures of 7 hearts of the wild pigs (Sus scrota) were observed by applying macroscopic and microscopic techniques and the findings were compared broadly to the literature. In all hearts examined, the tricuspid and mitral valves were normal and composed of 3 and 2 cusps, respectively. The papillary muscles observed in mammalian heart in general were found in both the ventricles; additionally, there were small unnamed papillary muscles in the left ventricle of the three samples. The sept marginal trabecula and false chords were present in the right ventricles, microscopically possessing myocardial fibres, connective tissue and Purkinje cells; while the false chords were located in all the left ventricles, but the sept marginal trabecula was found in the 3 samples only. Both the connective tissue and Purkinje cells were present in these two structures, but the myocardial fibres were not. Presence of the myocardial fibres in the right ventricle may have an effect on the ventricle geometry. (Folia Morphol 2017; 76, 4: 650-659)
\end{abstract}

Key words: left atrioventricular valve, right atrioventricular valve, sept marginal trabecula, wild pig

\section{INTRODUCTION}

Along with the obstruction in the vessels, infections, tumoural lesions, deficiencies, malformations, and anomalies of the valves and related components in heart affect the heart beat considerably. In most occasions, healthy heart beat can be achieved by repairing anomalies in the valves and related structures or replacing them. Having that in mind, observing detail peculiarities of the heart of the animals used particularly in research is essential. In this case it is the wild pig the morphology of whose heart is to be observed profoundly.
Heart valves, which are an extension of the endocardium, regulate blood flow constantly between the atriums and ventricles. Even though literature $[3,12,15,58]$ indicates that the right atrioventricular valve has three cusps and left atrioventricular valve possesses two, recent documents have reported different numbers and cases [21, 26, 38, 62, 64, 66]. Hence, several textbooks $[15,58]$ and reports $[3,5$, $35,46,59]$ have documented that species and individual variations may occur in the morphology of the papillary muscles and tendinous chords both joining in the functional mechanism of the valves.

Address for correspondence: Dr. F. Başak, Karabuk University, Faculty of Medicine, Department of Histology and Embriyology, Demir Çelik Campus, Karabuk, Turkey, tel: +90 3704187160-1192, fax: +90 370418 76 61, e-mail: vetfeyza@hotmail.com; vetfeyza@gmail.com; feyzabasak@karabuk.edu.tr 
As indicated above, morphology of the heart valves and related structures in several domestic and wild animals and human is amply documented. On the other hand, no study, as to our knowledge, has focused on the heart valves of the wild pig, the ancestor of the domestic pig which is widely used in heart-related studies. Therefore, this study was intended to observe the heart valves and related structures of the wild pig, since it is thought to be of value to document their morphology in these animal, and to compare the findings with the data acquired in the literature.

\section{MATERIALS AND METHODS}

Seven hearts of mature wild pigs were used in the study. The materials were fixed using $10 \%$ formaldehyde solution for dissection and taking tissue sample. The fixed hearts were cut of the coronary groove level and atria were removed. The walls of the ventricles were cut through the right and left interventricular grooves, from apex to the ostia. The valves and related structures were dissected and photographed. The atrioventricular valves, numbers of the papillary muscles, sept marginal trabecula, true and false tendinous chords were determined macroscopically.

For light microscopy, samples were obtained from the sept marginal trabecula, and the true and false tendinous chords of both ventricles. The tissues were fixed in the buffered formaldehyde solution (100 mL of formalin [37-40\% stock solution], $900 \mathrm{~mL}$ of distilled water, $4 \mathrm{~g} / \mathrm{L} \mathrm{NaH} \mathrm{PO}_{4}$ [monobasic], $6.5 \mathrm{~g} / \mathrm{L} \mathrm{NaH}_{2} \mathrm{PO}_{4}$ [dibasic/anhydrous]). Upon washing with tap water for $24 \mathrm{~h}$, the samples were dehydrated using alcohol series (70\% to $100 \%)$. After polishing the tissues using xylene, they were embedded in paraffin and $5 \mu$ slides were obtained using microtome (Leica RM2125RT). The slides were deparaffinised and hydrated to water and modified Crossman's staining technique [10] was applied to reveal general structure of the tissues. Following the mounting of the slides, they were examined under microscope and photographs were taken (CX21 Olympus binocular microscope, Olympus sc100 camera system, cell Sens Entry Computer Visualisation System).

Federative International Programme for Anatomical Terminology (2017) [27] and Nomina Anatomica Veterinaria (2012) [28] were applied for the anatomical nomenclature.

\section{RESULTS}

The right atrioventricular valves (Fig. $1 \mathrm{~A}-\mathrm{C}$ ) in all the hearts examined possessed the septal, anterior, and posterior cusps. The posterior cusps were rectangular (Fig. 1A, B), the septal cusps were semicircular (Fig. A-C), and the anterior cusps were either rectangular or triangular in shape (Fig. 1A, B). Additionally, the commissural (accessory) cusps number was as follows; 2 hearts had 2 cusps at posteroseptal commissure, 1 heart had 1 cusp at anteroseptal commissure, 2 hearts had 1 cusp and 3 hearts had 2 cusps at anteroposterior commissure (Fig. 1A, B).

The left atrioventricular valves in all the hearts observed were composed of the anterior and posterior cusps (Fig. 2A-C). The posterior cusps were rectangular, and the anterior cusps were semicircular in shape (Fig. 2A-C). Additionally, the commissural (accessory) cusps number was as follows: 4 hearts had 2 cusps and 3 hearts had 1 cusp at anterolateral commissure, 5 hearts had 1 cusp at posteromedial commissure (Fig. 1A, B).

In the right ventricle (RV), there were 1 septal papillary muscle and 1-4 posterior papillary muscles on the septal wall, and 1 anterior papillary muscle on the parietal wall (Table 1). The septal papillary muscles (Fig. 1A-C, E, F) located near the orifice of the pulmonary trunk were protuberance-like structures adhering tightly to the septal wall. Yet, a posterior papillary muscle in 1 heart was located on the junction of the parietal and septal walls while another was observed on the parietal wall (Fig. 1F). In another heart, 2 posterior papillary muscles were present on the junction of the parietal and septal walls (Fig. 1A). Shapes of the posterior papillary muscles found on the septal wall were a vestigial protuberance, nipple-like or a flat rectangle (Fig. 1A-C, E, F). Those found on the parietal wall and on the junction of the parietal and septal walls were finger-like structures, one of them having double apices (Fig. 1A, F). The anterior papillary muscles were either a flat cone or a cylinder in shape (Fig. 1A-D). One of the flat cone-shaped muscles had two muscular columns (Fig. 1D), one of which was emerging from the body and one - from the apex, while another muscle had two columns on the apex (Fig. 1A). These muscular columns were attached to the base of the parietal wall either directly or via tendinous chords.

Two papillary muscles were attached to the parietal wall in the left ventricle (LV) (Fig. 2A-C). The anterior papillary muscle was like a well-rounded cone possessing a pointed edge. The posterior papil- 


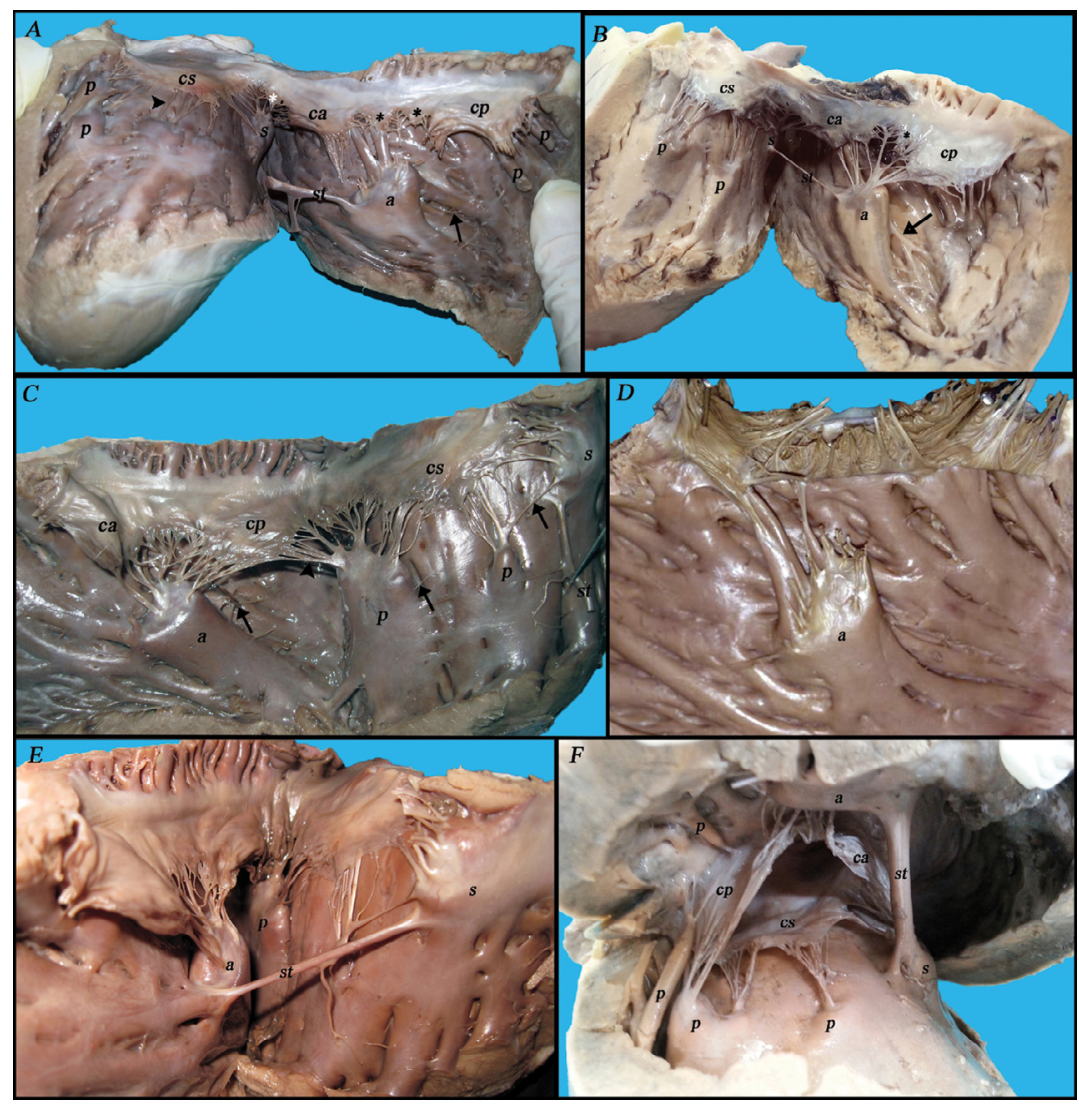

Figure 1. A-F. Intraventricular structures in the right ventricle; cs - septal cusp, ca - anterior cusp, white asterisk $\left(^{*}\right)$ - anteroseptal commissural (accessory) cusp, cp — posterior cusp, black asterisk $\left({ }^{*}\right)$ - anteroposterior commissural (accessory) cusps, a - anterior papillary muscle, $\mathrm{p}$ - posterior papillary muscles, $s$ - septal papillary muscle, st — sept marginal trabecula, arrowheads — tendinous chords, arrows — false tendinous chords.

lary muscle was also like well-rounded cone and had one (Fig. 2A) or two (Fig. 2B, C) belly. This muscle had one apex in 2 hearts, double apices in 4 hearts, and triple apices in 1 heart. Additionally, along with these muscles, 3 smaller nipple-like papillary muscles near the annulus of the parietal wall were observed in 1 heart, one on the upper half of the parietal wall between the two main papillary muscles in another heart, and one on the junction of the parietal and septal walls near the posterior papillary muscle in a third heart (Fig. 2A, D).

The number of the tendinous chords (Fig. 1A, C, $2 \mathrm{~A}, \mathrm{C})$ was 30-40 in the RV, and 25-35 in the LV (Table 1). Their structural nature was fibrous connective tissue (Fig. 3A, B).

In all the hearts examined, one sept marginal trabecula was observed, lying between the base of the anterior papillary muscle and base of the septal papillary muscle in the RV (Fig. 1A, B, E, F). Their length was $25-30 \mathrm{~mm}$, and their thickness $1-5 \mathrm{~mm}$. In 6 hearts, this structure was divided into two pieces, resembling " $Y$ " letter before attaching the septal papillary muscle (Fig. 1A, E, F). In light microscopy of this structure (Fig. 3 C), several Purkinje cells were seen located peripherally and enclosed by connective tissue, and myocardial fibres opposing them. Less frequency, blood vessels were also found among the myocardial fibres and in the connective tissue. Two to six false tendinous chords (Fig. 1A-C) were found also in the RV (Table 1). Upon histological examination, Purkinje cells located peripherally, myocardial fibres, connective tissue, and capillaries in the connective tissue were seen (Fig. 3E).

Two left sept marginal trabeculae were seen in 2 hearts (Fig. 2E), and 4 in 1 heart (Fig. 2F). The other 4 hearts possessed no left sept marginal trabecula. Two of these trabeculae lying between the posterior papillary muscle and the septal wall had three divisions on its origin and two on the other edge attaching the septal wall. Two other trabeculae had two divisions on the septal edge only, while another trabecula had three divisions. The length of the sept 


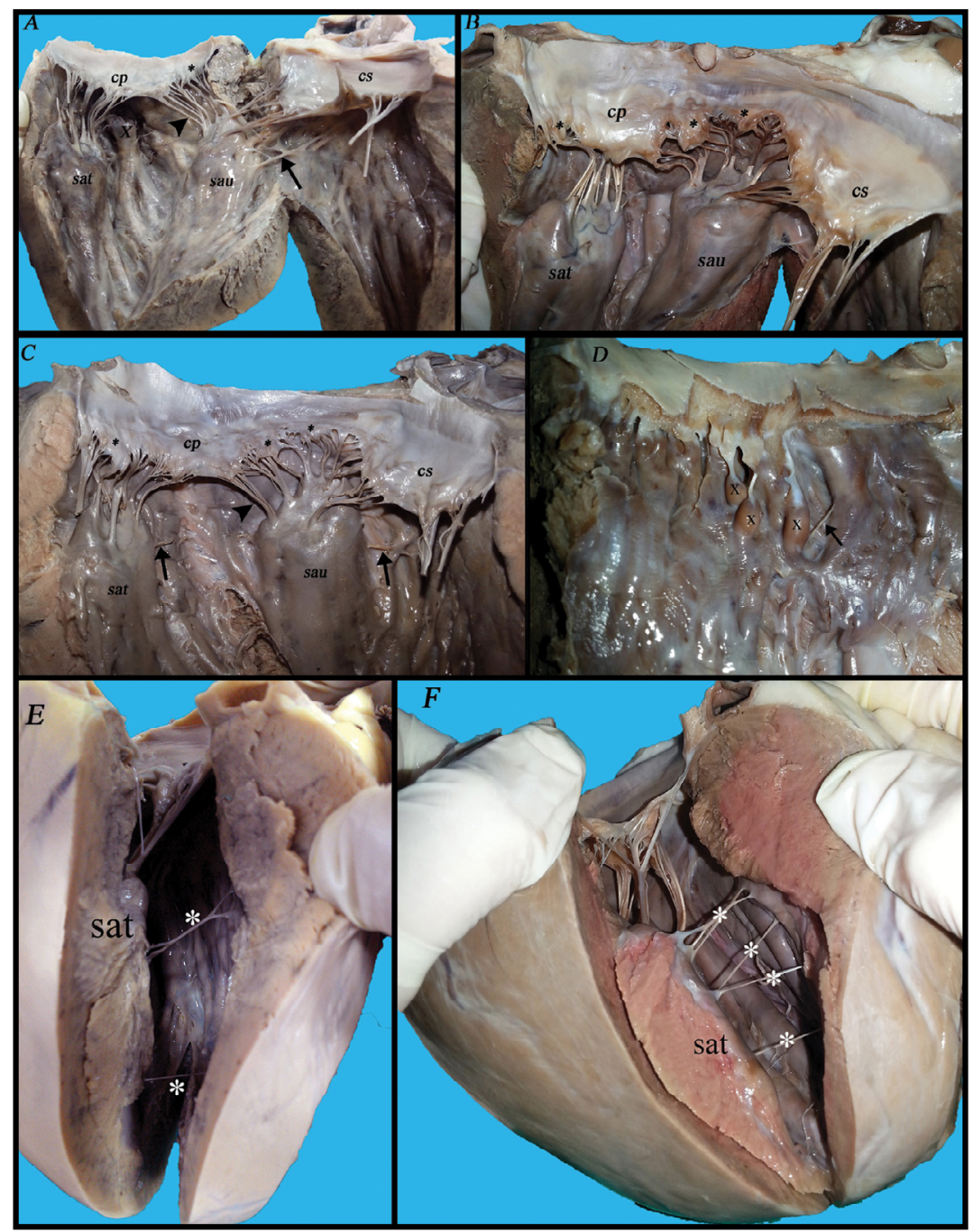

Figure 2. A-F. Intraventricular structures in the left ventricle; cs — anterior cusp, $c p$ - posterior cusp, black asterisk $\left(^{*}\right)$ - commissural (accessory) cusps, sau - anterior papillary muscle, sat — posterior papillary muscles, $x$ - unnamed papillary muscles, white asterisk $\left({ }^{*}\right)$ — sept marginal trabecula, arrowheads — tendinous chords, arrows — false tendinous chords.

Table 1. Numbers of the papillary muscles and fibres in the right and left ventricles

\begin{tabular}{|c|c|c|c|c|c|c|c|c|c|c|c|c|}
\hline \multirow{2}{*}{$\begin{array}{l}\text { No. } \\
\text { of specimens }\end{array}$} & \multicolumn{3}{|c|}{ PM (RV) } & \multicolumn{3}{|c|}{ PM (LV) } & \multirow[t]{2}{*}{ ST (RV) } & \multirow[t]{2}{*}{ ST (LV) } & \multirow[t]{2}{*}{ TC (RV) } & \multirow[t]{2}{*}{ TC (LV) } & \multirow[t]{2}{*}{ fTC (RV) } & \multirow[t]{2}{*}{ fTC (LV) } \\
\hline & $\mathbf{s}$ & a & $\mathbf{p}$ & sau & sat & $\mathbf{x}$ & & & & & & \\
\hline $1 \%$ & 1 & 1 & 4 & 1 & 1 & - & 1 & - & 35 & 30 & 4 & 5 \\
\hline $20^{\pi}$ & 1 & 1 & 1 & 1 & 1 & 1 & 1 & - & 38 & 29 & 2 & 5 \\
\hline $30^{\pi}$ & 1 & 1 & 2 & 1 & 1 & 3 & 1 & 4 & 32 & 31 & 3 & 2 \\
\hline $40^{x}$ & 1 & 1 & 1 & 1 & 1 & - & 1 & - & 36 & 30 & 4 & 3 \\
\hline 5우 & 1 & 1 & 3 & 1 & 1 & - & 1 & 2 & 40 & 33 & 2 & 4 \\
\hline 6우 & 1 & 1 & 4 & 1 & 1 & - & 1 & - & 34 & 35 & 6 & 2 \\
\hline 7우 & 1 & 1 & 1 & 1 & 1 & 1 & 1 & 2 & 30 & 25 & 5 & 8 \\
\hline
\end{tabular}

PM — papillary muscles; ST — sept marginal trabecula; TC — tendinous chord; fTC — false tendinous cord; RV — right ventricle; LV — left ventricle; s — septal papillary muscle; $\mathrm{a}$ — anterior papillary muscle; $\mathrm{p}$ - posterior papillary muscle; sau — subauricular papillary muscle; sat — subatrial papillary muscle; $\mathrm{x}$ — unnamed papillary muscle 


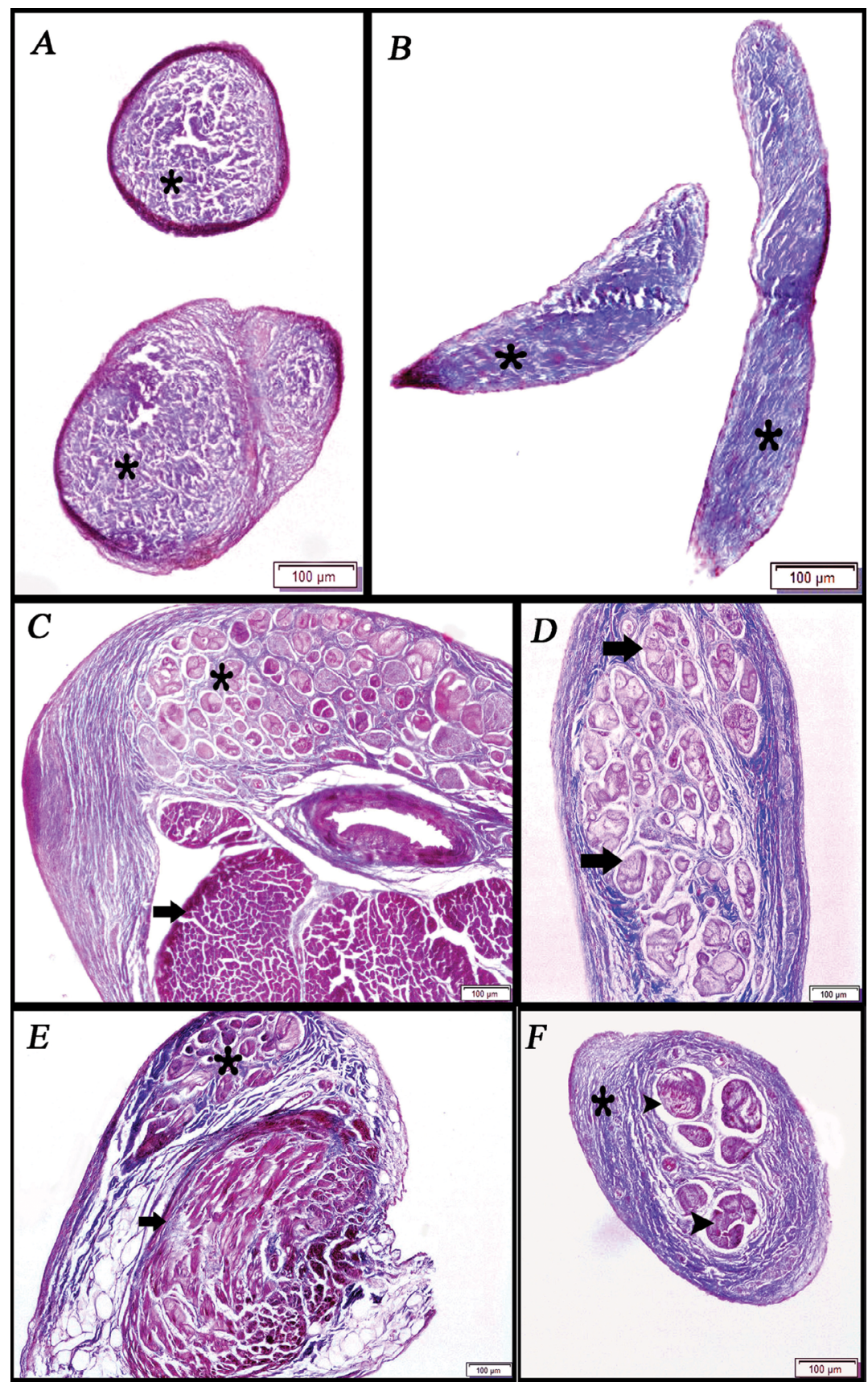

Figure 3. Histological appearance of the filamentous structures in the heart ventricles; A. Tendinous chords in the right ventricle, $\left({ }^{*}\right)$ connective tissue; B. Tendinous chords in the left ventricle, $\left({ }^{*}\right)$ connective tissue; C. Septomarginal trabecula in the right ventricle, $\left({ }^{*}\right)$ Purkinje cells, arrow - muscle tissue; D. Septomarginal trabecula in the left ventricle, arrows — Purkinje cells; E. False tendinous chords in the right ventricle, $\left(^{*}\right)$ Purkinje cells, arrow - muscle tissue; F. False tendinous chords in the left ventricle, arrow head — Purkinje cells, $\left({ }^{*}\right)$ connective tissue.

marginal trabeculae was $10-20 \mathrm{~mm}$, and the thickness was $0.5-2 \mathrm{~mm}$. Light microscopic examination revealed Purkinje cells roughly similar in size, encircled by a sheath of the connective tissue. No myocardial fibre was determined in the left sept marginal trabecula (Fig. 3D). There were $2-8$ false tendinous chords (Fig. 2A, C, D) in the LV (Table 1). Histological examination of this structure showed that Purkinje cells were located centrally in the fibrous connective tissue without forming a sheath. Capillaries were scattered in the tissue, but no myocardial fibres were present (Fig. 3F). 


\section{DISCUSSION AND CONCLUSIONS}

There are two different views on determining the number of the cusps of the right atrioventricular valve. Some literature $[12,15,34,55,58,59,65]$ indicated that the right atrioventricular valve possesses anterior, septal and posterior cusps, with the posterior one displaying sectional nature. Yet, other reports $[5,26,29,43,60,64-66]$ showed that the anterior and posterior cusps may occasionally fuse. They also indicated presence of the "supernumerary", "accessory" or "commissural" cusps, along with the three cusps. The number of these "supernumerary", "accessory" or "commissural" cusps may be 1-2 $[2,21,64], 1-3[66]$, or $1-4[29,36,43,60]$. In this study, all of the hearts had three eminent cusps and one or two commissural (accessory) cusps.

The shape of the posterior cusp was shown to be semicircular [59], triangular, rectangular or square $[43,45]$. Likewise, the posterior cusps in this study were rectangular in shape. Literature described the shape of the septal cusp to be triangular [43], semioval [59] or semicircular [5], and rarely rectangular [43, $45,59]$. The septal cusps examined in this study were semicircular and their unique structure was similar to that in literature. Similarly, the shape of the anterior cusps was found to be semicircular [59], triangular $[43,45]$, or rarely rectangular $[43,45,59]$. The results of our study were also in parallel with the literature.

In certain studies, it was documented that the left atrioventricular valve was formed of two cusps; anterior and posterior, and the small pieces located between these two main cusps were parts of the posterior cusp, [7, 12, 24, 30, 52]. Other reports $[3,15,21,38,58]$ also mentioned that there may be small "accessory", "supernumerary" or "commissural" pieces between the two main cusps. The number of the commissural (accessory) cusps may be 1-2 [21], 1-3 [38] or 1-4 [19]. According to the researches accepting the accessory cusps as the scallops of the posterior cusp [30,52], the number of the scallops vary from 1 to 5 . In this study, hearts had 2 eminent cusps and 1-3 commissural (accessory) cusps. The shape of the anterior cusp was shown as semicircular and triangular [30,42,52] or rectangular [42], while that of the posterior cusp as semioval [52], triangular or rectangular [42]. The results of our study were also in parallel with the literature.

Shapes and numbers of the papillary muscles in the RV were documented to vary $[5,21,29,58]$. The septal and posterior papillary muscles were shown to be located on the septal wall, while the anterior papillary muscle on the parietal wall $[3,13,15,21$, 29]. Again, the anterior papillary muscle in the Guinea pig is located either between the junction of the two walls on the apical region [5] or on the septal wall as is the case in mouse [26], rabbit [5] and dogs [2,58]. In our study, the septal papillary muscle was found on the septal wall, while the anterior papillary muscle was located on the parietal wall, which is in resemblance to some reports $[3,13,15,21]$ but contrary to others $[2,5,26,58]$. Likewise, the posterior papillary muscle was present on the junction of the two walls in the three, on the parietal wall in the one, and on the septal wall in the rest of the samples.

Of the three papillary muscles in the RV, the septal papillary muscle was observed either to be single or to lack $[2,22,29,41,46]$, or to be one-two [5, 22], one-three [41]. Tendinous chords arising directly from the septal wall were documented in the case of their lack $[41,61]$. Their shapes were indicated as either finger-like or nipple-like protuberance [5, 21, 29]. In this study, one septal papillary muscle was observed in each sample examined, located on the septal wall as a protuberance. It had a unique tip, contrary to some reports $[21,46]$. Likewise, literature reported the number of the posterior papillary muscles as mostly two [35, 46], one [13], one-five [5, 29], two-three [21] or zero-seven [23]. The tip of this muscle was shown to have subtips of different numbers [21, $29,46]$. The number of these muscles in our study was one-four, only one had two heads. Literature documented the number of the anterior papillary muscles to be one $[5,15,21,46,58]$, one-two [2], one-three [22,34] or one-four [29]. This number was one in each sample examined in this study, and the muscle possessed no heads or bellies, contrary to some literature $[21,29,35,46]$.

Peculiarities of the posterior and anterior papillary muscles on the parietal wall of the LV were amply reported in several textbooks $[3,12,15,58]$ and papers $[9,26,53,54]$. Erdoğan et al. [13] indicated that location of the posterior papillary muscle in the LV is fixed in the heart of rhinoceros, while the anterior papillary muscle lies on the septal wall. Reports in rabbit [5] and human [50] also documented smaller muscle masses along with these two main muscle groups. The number of the papillary muscles in the LV was reported as two-four $[20,38]$. However, this study found one anterior and one posterior papillary muscle in the LV, along with smaller papillary muscles. 
Studies revealed the shape of the papillary muscles in the $L V[5,7,53,54]$. Özbağ et al. [50] reported their shapes in human to be "V", "Y", and " $\mathrm{H}$ ", indicating more than one belly being either cone- or nipple-like in animals. The anterior papillary muscle in our study was a flat cone-like in shape, ending with a distinct tip, while the posterior papillary muscle had either one or two bellies, being well rounded in shape.

The number of tendinous chords in the RV was reported to be 24-25 in human [59], 23 in domestic pig, 22 in sheep, 25 in cattle [25], 20 in rabbit and 18 in Guinea pig [5]. This study found this number between 30 and 40 . In the LV, the number of tendinous chords has been documented as 23-24 in human [47, 49], 20 in primates [17], 16 [25] or 78 [38] in domestic pig, and 16 in dog, 12 in goat, and 11 in sheep [49]. Similarly, the number of tendinous chords in the LV was found to be $25-35$ in this study. This structure was also revealed to be completely fibrous tissue in our study, just as documented previously in sheep, goat, dog and human [49], and in donkey [21].

Presence of the sept marginal trabecula in both ventricles was indicated by several reports $[6,8,9,14$, $16,18,21,57,63]$. There was a firm consensus on naming the sept marginal trabecula (the moderator band) in the RV while different names were applied for the fibres in the LV which do not attach the cusps. Some reports also named the false tendinous chords as the sept marginal trabecula $[4,18]$. Others called them "the left ventricular band" [11, 14], "false chords" or "abnormal chords" [17, 31, 39, 49,56], or "the sept marginal trabecula (the moderator band)" particularly stressing their attachment sites $[13,16,18,21,63]$. The Nomina (2012) [28] used singular name for the sept marginal trabecula in the RV, while using plural name for it in the LV to indicate their numbers. This study also followed the Nomina (2012) [28] for the nomenclature.

Truex and Warshaw [63] reported no right sept marginal trabecula in the hearts of 12 dogs, while they showed that $56.85 \%$ of the 400 human hearts, $51 \%$ of the 100 cat hearts, $41.6 \%$ of the monkey hearts, and all of the 12 sheep, pig, and cattle hearts had this structure. Additionally, Kosiński et al. [33] documented the lack of this structure in the heart of the lemur. Similarly, our study found one sept marginal trabecula in each $\mathrm{RV}$ dissected, as reported by the literature $[6,8,9,13,14,16,21,56]$, except for the results of a few other studies $[33,63]$. This structure was shown to extend from parietal wall to the anterior papillary muscle $[5,6,8]$, from septal wall to the either anterior papillary muscle or parietal wall $[16,21]$, or from the base of the septal papillary muscle to the either anterior papillary muscle or parietal wall [18]. Several studies $[5,6,8,18,21]$ indicated the shape of the sept marginal trabecula to vary in different species. In our study, it lied between the septal papillary muscle and anterior papillary muscle and, except the one, was " $Y$ " in shape. This bifurcation was determined on the side of the septal papillary muscle, contrary to the findings of Gulyaeva and Roshchevskaya [18]. They found the bifurcation on the parietal wall side of the trabecula in domestic pig. They hence mentioned additional thin moderator bands in the RV, but we observed no such structures.

Literature documented the length and thickness of the sept marginal trabecula. It is thicker and closer to the base of the RV in pig, as compared to human [9]. The thickness was reported to be 2-7.7 $\mathrm{mm}$ [18] and 1-7 $\mathrm{mm}$ in domestic pig [63], $5 \mathrm{~mm}$ in goat [37], and 2-6 mm in cat, $1-3.5 \mathrm{~mm}$ in monkey, $2-4 \mathrm{~mm}$ in sheep, 1-12 mm in cattle, 1.5-14 mm in human [63], and 2-7 $\mathrm{mm}$ in human [51]. Likewise, the length was documented as $13-26 \mathrm{~mm}$ goat [37], and 15-24 mm in sheep, 3-8 mm in monkey, 3-9 mm in cat, $15-51 \mathrm{~mm}$ in domestic pig, $20-30 \mathrm{~mm}$ in cattle, $3.5-29 \mathrm{~mm}$ in human [63] and 8.82-22.3 $\mathrm{mm}$ in human [51]. In our study, the length and thickness were measured as $25-30 \mathrm{~mm}$ and $1-5$, respectively.

Histological studies revealed connective tissue, myocardial fibres and Purkinje cells in the sept marginal trabecula of the RV $[6,16,18,21,57]$. Gulyaeva and Roshchevskaya [17] indicated in domestic pig that conductive Purkinje cells encircle vessels, being present both centrally and peripherally. These results are similar to our findings [44]. Also reported muscle fibres in the right sept marginal trabecula on domestic pig, along with Purkinje cells, located peripherally, and conductive cells found centrally in the trabecula. This literature also stressed that Purkinje cells lie either alone or in groups, enclosed by the connective tissue but it is not a sheath like structure. In our study, however, Purkinje cells were divided in groups only surrounded by connective tissue, which might be a unique nature of the hearth of the wild pig.

The left sept marginal trabecula was documented in domestic pig [18], camel [16], donkey [21], rhinoceros [13], rabbit and Guinea pig [5]. Their number was reported as 1-3 in domestic pig [18], rhinoceros [13], and rabbit and Guinea pig [5], 2 in camel [16], and 1-5 in donkey [21]. Gerlis et al. [14] estimated 
the presence ratio of this structure on the $\mathrm{LV}$ as $48 \%$ in human, $86 \%$ in pig, $92 \%$ in cattle, and $100 \%$ in sheep, horse, cat and dog. Deniz et al. [11] found this ratio as $47 \%$ in human, $77 \%$ dog, $92 \%$ in sheep, and $88 \%$ in goat. Thickness of the structure was also measured as $1-3 \mathrm{~mm}[11,18]$ while the length was found as $6.5-21.5 \mathrm{~mm}$ in donkey [21], 7-52 $\mathrm{mm}$ in human, 6-35 $\mathrm{mm}$ in dog, 6-31 $\mathrm{mm}$ in sheep, and 7-37 mm in goat [11]. In our study, on the other hand, the left sept marginal trabecula was observed in the three samples; 2 in 2 hearts and 4 in 1 heart. Their thickness and length were $0.5-2 \mathrm{~mm}$ and $10-20 \mathrm{~mm}$, respectively. Thus, their histological examination revealed connective tissue, myocardial fibres and Purkinje cells $[11,16,18]$. Particularly, Gulyaeva and Roshchevskaya [18] reported that in pig heart Purkinje cells are enclosed by the myocardial fibres and the tissue contains a few blood vessels. However, our study found connective tissue and Purkinje cells but no myocardial fibres, which was different from the findings of the study on domestic pig [18].

Ghonimi et al. [16] searched the left sept marginal trabecula in camel, indicating that it possesses two distinct layer, myocardium centrally and endocardium peripherally. They also reported modified myocardial cells of two different types (small and large calls), which is quite different from the findings in the wild pig.

Reports indicated presence of the false tendinous chords both in the left $[1,5,31,39,48,49,56]$ and right $[32,40]$ ventricles. The presence ratio of this structure in the LV was found as 34\% [1] and $60-62 \%$ $[31,39,48,49,56]$ in human while more than $65 \%$ in various animals $[5,31,48,49]$. Histological observations revealed connective tissue, myocardial fibres, Purkinje cells and blood vessels in this structure $[1,11,40,48,49,56]$. Saji et al. [56], thus, defined the false chords including connective tissue only as fibrous type, those additionally possessing myocardial fibres as fibromuscular type, and those having also Purkinje cells, along with previous two, as muscular type. Accordingly, literature mostly reported fibrous and fibromuscular types in human $[48,49,56]$ while muscular type is present rarely. The false chords in the LV of various animals such as sheep, goat and dog reportedly included Purkinje cells $[48,49]$; thus, indicating the presence ratio of both false chords and Purkinje cells in this chords being higher in animals than in human [31, 48, 49]. In our study, the false chords examined in the LVs of the wild pig was con- sidered as fibrous type since they contained Purkinje cells and connective tissue but no myocardial fibres.

There are very few reports that describe the false chords in the RVs. Their presence ratio was $35-100 \%$ in human [5, 32, 40]. Yet, Ateş [5] found no false chords in the RVs of the rabbit and Guinea pig. Loukas et al. [40] documented that $41.6 \%$ of the false chords contain connective tissue, Purkinje cells and myocardial cells, and the rest having connective tissue only, but we have found false chords and Purkinje cells in this cords every RVs examined.

Consequently, the left and right atrioventricular valves of the hearth and the related structures were broadly observed in the wild pig at macro- and microanatomical aspects. All the papillary muscles commonly seen in mammalian heart were eminently present, yet there were small unnamed papillary muscles in the LV of the three samples. The sept marginal trabecula and false chords were eminent in the RVs, histologically containing myocardial fibres, connective tissue and Purkinje cells, while the false chords were present in all the LVs but the sept marginal trabecula was found in the three samples only. And both the connective tissue and Purkinje cells were present in these two structures but no myocardial fibres were found. Presence of the myocardial fibres in the RV may have an effect on the ventricle geometry. Thus, presence of the Purkinje cells in both ventricles may lead to harmless murmur and arrhythmia, as suggested by the literature.

\section{REFERENCES}

1. Abdulla A, Frustaci A, Martinez J, et al. Echocardiography and Pathology of Left Ventricular "False Tendons". Chest. 1990; 98(1): 129-132, doi:10.1378/chest.98.1.129.

2. Alves JR, Wafae N, Beu CC, et al. Morphometric study of the tricuspid valve in dogs. Anat Histol Embryol. 2008; 37(6): 427-429, doi: 10.1111/j.1439-0264.2008.00872.x, indexed in Pubmed: 18798836.

3. Arıncı K, Elhan A. Anatomi, 2. cilt, 5. Baskı. Güneş Kitabevi Ltd.Şti., Ankara 2014

4. Armiger LC, Urthaler F, James TN. Morphological changes in the right ventricular sept marginal trabecula (false tendon) during maturation and ageing in the dog heart. J Anat. 1979; 129(Pt 4): 805-817, indexed in Pubmed: 536316.

5. Ateş S. Yeni Zelanda tavşanı ve kobayda kalp kapaklarının karşılaştırmalı makro anatomisi, Üniversitesi Sağlık Bilimleri Enstitüsü. Doktora Tezi, Ankara 2004.

6. Bombonato PP, Mariana ANB, Borelli V, et al. Morphometric study of trabecula septomarginalis in dogs. Ars Veterinaria. 2012; 28(4): 250-254.

7. Bozbuğa N, Şahinoğlu $K$, Öztürk $A$, et al. Mitral kapak ve subvalvuler apparatusun morfolojik özellikleri; ìst. Tıp Fak Mecmuası. 1998; 61(2): 1-4. 
8. Cope LA. Morphological Variations in the Canine (Canis familiaris) Right Ventricle Trabecula Septomarginalis Dextra and a Proposed Classification Scheme. Anat Histol Embryol. 2015; 45(6): 437-442, doi: 10.1111/ ahe.12217.

9. Crick SJ, Sheppard MN, Ho SY, et al. Anatomy of the pig heart: comparisons with normal human cardiac structure. J Anat. 1998; 193(Pt 1): 105-119, indexed in Pubmed: 9758141.

10. Denk H, Künzele H, Plenk H. Romeis Mikroscopische Technik. 17, Neuarbeite Auflage. Urban und Schwarzenberg München, Wien, Baltimore 1989: 439-450.

11. Deniz M, Kilinç M, Hatipoglu ES. Morphologic study of left ventricular bands. Surg Radiol Anat. 2004; 26(3): 230-234, doi: 10.1007/s00276-003-0212-0, indexed in Pubmed: 14648038.

12. Dursun N. Veteriner Anatomi II, 12. Baskı. Medisan Yayınevi, Ankara 2008: 186-202.

13. Erdoğan S, Lima $M$, Pérez W. Inner ventricular structures and valves of the heart in white rhinoceros (Ceratotherium simum). Anat Sci Int. 2014; 89(1): 46-52, doi: 10.1007/ s12565-013-0199-5, indexed in Pubmed: 23979858.

14. Gerlis LM, Wright HM, Wilson N, et al. Left ventricular bands. A normal anatomical feature. Br Heart J. 1984; 52(6): 641-647, indexed in Pubmed:6508964.

15. Getty R. Sisson and Grossman's: The Anatomy of the Domestic Animals, Vol: 2, 5. Ed. WB. Saunders Company, New York, USA 1975: 1300-1320.

16. Ghonimi W, AbuelAtta A, Bareedy M, et al. Gross and microanatomical studies on the moderator bands (septomarginal trabecula) in the heart of mature Dromedary camel (Camelus dromedarius). J Adv Vet Animal Res. 2014; 1(2): 24, doi: 10.5455/javar.v1i2p24-31.

17. Grzybiak M. Number of left ventricular chordae tendineae in primates; Folia Morphol. 1982; 41: 483-491.

18. Gulyaeva AS, Roshchevskaya IM. Morphology of moderator bands (septomarginal trabecula) in porcine heart ventricles. Anat Histol Embryol. 2012; 41(5): 326-332, doi: 10.1111/j.1439-0264.2012.01139.x, indexed in Pubmed: 22348232.

19. Gunnal SA, Farooqui MS, Wabale RN. Study of mitral valve in human cadaveric hearts. Heart Views. 2012; 13(4): 132-135, doi: 10.4103/1995-705X.105729, indexed in Pubmed: 23439693.

20. Gunnal SA, Wabale RN, Farooqui MS. Morphological variations of papillary muscles in the mitral valve complex in human cadaveric hearts. Singapore Med J. 2013; 54(1): 44-48, indexed in Pubmed: 23338917.

21. Halıgür A, Dursun N. Morphological and morphometric investigation of the musculus papillaris and chordae tendineae of the donkey (Equus asinus L). J Animal Vet Adv. 2009; 8(4): 726-733.

22. Harsha BR, Dakshayani KR. Morphometric study on septal papillary muscles of human tricuspid valve. Global J Med Res. 2014; XIV(I): 4-7.

23. Harsha BRB, Chandrashekar KT. Cadaveric study on anterior and posterior papillary muscles of tricuspid valve. Int J Anat Res. 2015; 3(1): 865-868, doi: 10.16965/ ijar.2015.103.

24. Ho SY. Anatomy of the mitral valve. Heart. 2002; 88(Suppl. 4): 5iv-10, doi: 10.1136/heart.88.suppl_4.iv5.
25. Hutchison J, Rea P. A comparative study of the morphology of mammalian true chordae tendineae of the atrioventricular valves. J Morphol Scien. 2015; 32(2): 71-77, doi: $10.4322 /$ jms. 073714 .

26. Icardo JM, Arrechedera H, Colvee E. The atrioventricular valves of the mouse. I. A scanning electron microscope study. J Anat. 1993; 182(Pt 1): 87-94, indexed in Pubmed: 8509303.

27. International Programme for Anatomical Terminology (FIPAT). http://www.unifr.ch/ifaa/Public/EntryPage (Access date: 04.25.2017).

28. International Committe on Veterinary Gross Anatomical Nomenclature General Assembly of the World Association on Veterinary Anatomists. Nomina Anatomica Veterinaria. 5th Ed., Gent 2012.

29. Joudinaud TM, Flecher EM, Duran CMG. Functional terminology for the tricuspid valve. J Heart Valve Disease. 2006; 15: 382-388.

30. Karaca Ö, Unur E, Acer N, et al. Insan kalbinde mitral kapağa ait cuspis'lerin morfolojik ve morfometrik incelenmesi. Erciyes Üniversitesi Sağlık Bilimleri Dergisi. 2003; 12(3): 44-51.

31. Kervancioğlu M, Ozbağ D, Kervancioğlu P, et al. Echocardiographic and morphologic examination of left ventricular false tendons in human and animal hearts. Clin Anat. 2003; 16(5): 389-395, doi: 10.1002/ca.10152, indexed in Pubmed: 12903060.

32. Kosiński A, Grzybiak M, Dubaniewicz A, et al. False chordae tendineae in right ventricle of adult human hearts - morphological aspects. Arch Med Sci. 2012; 8(5): 834-840, doi: 10.5114/aoms.2012.31617, indexed in Pubmed: 23185192.

33. Kosiński A, Zajączkowski M, Kuta W, et al. Septomarginal trabecula and anterior papillary muscle in primate hearts: developmental issues. Folia Morphol. 2013; 72(3): 202-209, indexed in Pubmed: 24068681.

34. Kujur B, Thakur N, Prasad R. Morphological study of tricuspid valve and its variations in adult human hearts. IOSR J Dental Med Sciences. 2016; 15(09): 72-78, doi: 10.9790/0853-1509017278.

35. Kumar S, Singh AK, Tamang BK. A morphological and morphometric study of the right ventricular papillary muscles in North Indian Region. NJIRM. 2015; 6(4): 52-55.

36. Lama P, Tamang BK, Kulkarni J. Morphometry and aberrant morphology of the adult human tricuspid valve leaflets. Anat Sci Int. 2016; 91(2): 143-150, doi: 10.1007/s12565015-0275-0, indexed in Pubmed: 25677415.

37. Leão CR, Pacha DL, Cyriaco T, et al. Anatomy of the sept marginal trabecula in goat hearts. Ital J Anat Embryol. 2010; 115(3): 229-234, indexed in Pubmed: 21287978.

38. Lima JV, Almeida J, Bucler B, et al. Anatomy of the left atrioventricular valve apparatus in landrace pigs. J Morphol Sci. 2013; 30(1): 63-68.

39. Loukas M, Louis RG, Black B, et al. False tendons: an endoscopic cadaveric approach. Clin Anat. 2007; 20(2): 163-169, doi: 10.1002/ca.20347, indexed in Pubmed: 16944521.

40. Loukas M, Wartmann CT, Tubbs RS, et al. Right ventricular false tendons, a cadaveric approach. Surg Radiol Anat. 2008; 30(4): 317-322, doi: 10.1007/s00276-008-0326-5, indexed in Pubmed: 18283389. 
41. Loukas M, Tubbs RS, Louis RG, et al. An endoscopic and anatomical approach to the septal papillary muscle of the conus. Surg Radiol Anat. 2009; 31(9): 701-706, doi: 10.1007/ s00276-009-0510-2, indexed in Pubmed: 19415160.

42. Mishra PP, Manvikar PR, Paranjape V, et al. Variations in the shape of atrioventricular cusps. Heart India. 2015; 3(2): 39-42, doi: 10.4103/2321-449x.158871.

43. Mishra PP, Manvikar PR, Mishra A, et al. Variations in the number and morphology of cusps of the tricuspid valve: A cadaveric study. Int J Biomed Res. 2016; 7(1): 39-43.

44. Moller FB, Jensen JT. On nerves and nerve endings in the conducting system of the moderator band (septomarginal trabecula). J Anat. 1971; 108(3): 387-395.

45. Motabagani MAB. Comparative anatomical, morphometric and histological studies of the tricuspid valve-complex in human and some mammalian hearts; J. Anat Soc. 2006; 55(1): 1-23.

46. Nigri GR, Di Dio $\sqcup$, Baptista CA. Papillary muscles and tendinous cords of the right ventricle of the human heart: morphological characteristics. Surg Radiol Anat. 2001; 23(1): 45-49, indexed in Pubmed: 11370142.

47. Önderoğlu S, Başar R, Akşit D. Ventriculus sinister'de bulunan chordae tendineae'nin morfolojik incelenmesi; Hacettepe. Tıp Dergisi. 1988; 21(2): 97-103.

48. Özbağ D, Kervancıoğlu P, Kervancıoğlu M. Sol ventrikülde yalancı chordae tendineae. Sendrom. 2002: 85-89.

49. Özbağ D, Kervancıoğlu P, Saruhan B, et al. Farklı türlerde sol ventriküldeki gerçek chordae tendineae ile yalancı chordae tendineae'nin morfolojik ilişkisinin karşılaştırmalı olarak incelenmesi. Türk J Vet Anim Sci. 2003; 27: 133-140.

50. Ozbag D, Gumusalan Y, Demirant A. The comparative investigation of morphology of papillary muscles of left ventricle in different species. Int J Clin Pract. 2005; 59(5): 529-536, doi: 10.1111/j.1742-1241.2004.00345.x, indexed in Pubmed: 15857348.

51. Raghavendra AY, Kavitha A, Kumar P, et al. Anatomical study of the moderator band. Nitte University J Health Scien. 2013; 3(4): 78-81.

52. Ranganathan N, Lam J, Wigle ED, et al. Morphology of the human mitral valve: II. The valve leaflets. Circulation. 1970; 41(3): 459-467, doi:10.1161/01.cir.41.3.459.

53. Roberts WC, Cohen LS. Left ventricular papillary muscles. Circulation. 1972; 46: 138-154.
54. Roberts WC. Morphologic features of the normal and abnormal mitral valve. Am J Cardiol. 1983; 51(6): 1005-1028, indexed in Pubmed: 6338691.

55. Rohilla A, Singh K. Tricuspid valve morphometry: a new learning from cadavers. Anat Physiol. 2015; 05(04), doi: 10.4172/2161-0940.1000185.

56. Saji $\mathrm{P}$, Cherian KM, Wu MH, et al. Left ventricular false tendons: echocardiographic, morphologic, and histopathologic studies and review of the literature. Pediatr Neonatol. 2011; 52(5): 279-286, doi: 10.1016/j.pedneo.2011.06.007, indexed in Pubmed: 22036224.

57. Sathyamoorthy OR, Ramesh G. Microanatomical studies on the moderator band (trabecula septomarginalis) of horses (Equus caballus). J Vet Anim Sci. 2008; 39: 33-35.

58. Schummer A, Wilkens $H$, Vollmerhaus B. The Circulatory System, the Skin, and the Cutaneous Organs of the Domestic Mammals, vol. 3. Verlag Paul Parey, Hamburg, Germany 1981: 15-70.

59. Silver MD, Lam JH, Ranganathan N, et al. Morphology of the human tricuspid valve. Circulation. 1971; 43(3): 333-348, indexed in Pubmed: 5544987.

60. Skwarek M, Grzybiak M, Kosinski A, et al. et al.. Notes on the morphology of the tricuspid valve in the adult human heart. Folia Morphol. 2004; 63(3): 319-324.

61. Skwarek M, Hreczecha J, Grzybiak M, et al. Remarks on the morphology of the papillary muscles of the right ventricle. Folia Morphol. 2005; 64(3): 176-182, indexed in Pubmed: 16228952.

62. Skwarek M, Hreczecha J, Dudziak M, et al. The morphology of the rihgt atrioventricular valve in the adult human heart. Folia Morphol. 2006; 65(3): 200-208.

63. Truex RC, Warshaw $\sqcup$. The incidence and size of the moderator band in man and in mammals. Anat Record. 1942; 82(3): 361-372, doi:10.1002/ar.1090820309.

64. Ülger H, Acer N, Karaca Ö, et al. İnsan kalbinde tricuspid kapağa ait cuspis'lerin morfolojik ve morfometrik incelenmesi; Erciyes Üniversitesi Sağlık Bilimleri Dergisi. 2003; 12(3): 58-63.

65. Victor S, Nayak VM. The tricuspid is bicuspid. J Heart Valve Disease. 1994; 3: 27-36.

66. Wafae N, Hayashi H, Gerola LR, et al. Anatomical study of the human tricuspid valve. Surg Radiol Anat. 1990; 12(1): 37-41, indexed in Pubmed:2345895. 